\title{
Landscaping Pre-Service Teachers' Stress Caused by Lack of Financial Management
}

\author{
Ramesh Rao Ramanaidu (PhD) \\ Institute of Teacher Education, Ilmu Khas Campus, Malaysia \\ E-mail: rameshrao08@yahoo.com \\ Sharmini Ghanaguru $(\mathrm{PhD})$ \\ Institute of Teacher Education, International Languages Campus, Malaysia \\ E-mail: sharmini.ghanaguru@gmail.com \\ Assunta Carolina Antonysamy $(\mathrm{PhD})$ \\ Institute of Teacher Education, Ilmu Khas Campus, Malaysia \\ E-mail: carolina_carolyn@ hotmail.com \\ Sadhna Nair-Prakash $(\mathrm{PhD})$ \\ Bukit Rahman Putra Secondary School, Malaysia \\ E-mail: sadhnanairprakash@gmail.com
}

Received: July 18, 2018 Accepted: August 3, 2018 Published: September 4, 2018

doi:10.5296/ber.v8i3.13394 URL: https://doi.org/10.5296/ber.v8i3.13394

\begin{abstract}
Age plays an important role in the financial behaviour of people. Financial matters are usually more seriously perceived at later stages of life. Nevertheless, the role of age in financial behavior is inconclusive. This study intends to add to the literature on financial behavior by focusing on the relationship between expenditure planning, gender and stress. The distinctive feature of this study is its scope and the sample of people participating in it. Besides being young, the participants are pre-service teachers. Hence, studying their financial behavior also augurs well for the nation, for these are the shapers of its future. Using an
\end{abstract}


online survey, 127 pre-service teachers responded to 17 questions, dwelling mainly on their financial behavior. Logistic regression was then used to identify whether expenditure planning is related to stress and gender. The findings reveal that the failure to plan one's expenditures could cause stress and in which gender could be the determinant factor. Thus, it is recommended to take actions on higher rate of financial literacy among pre-service teachers.

Keywords: Financial behaviour, Expenditure planning, Stress, Pre-service teachers

JEL Classification: G40, G4, M59.

\section{Introduction}

Financial management is a crucial concern in today's world. The ability to manage finances wisely indeed has its positive impact on the growth of an individual, both personal and professional. As such, one needs to be aware that financial success depends highly on the ability to use money effectively and within a stipulated budget.

There are many variables impacting the financial stability of individuals. There are also many reasons for weak financial stability, including: poor budgeting, inadequate savings and excessive debt. Irrespective of how much one earns, one should be aware that financial success depends on the ability to save and budget.

An important factor playing a significant role in money management is age. People between 36 and 40 were more likely to follow a planned budget than those in other age categories (Henry, Weber, \& Yarbarough, 2001). However, the role of age in explaining financial behaviour is inconclusive. Grable \& Joo (2006) studied the financial behaviour of college students but were unable to find any evidence to prove that age significantly influences financial behaviour. Table 1 shows the savings rate of Malaysians by age. Assuming that with good money management, one would be able to save more, therefore we can see that people in the age group 36 to 55 have higher rates of savings as shown in Table 1.

Table 1 . Savings rate by age (Malaysians)

\begin{tabular}{|c|c|}
\hline Age & Total Savings (\%) \\
\hline $16-25$ & 2.6 \\
\hline $26-30$ & 7.78 \\
\hline $31-35$ & 12.28 \\
\hline $36-40$ & 15.63 \\
\hline $41-45$ & 18.35 \\
\hline $46-50$ & 18.42 \\
\hline $51-55$ & 14.88 \\
\hline $56-60$ & 5.9 \\
\hline $61-65$ & 2.66 \\
\hline $66-70$ & 1.09 \\
\hline $71-75$ & 0.36 \\
\hline $76-80$ & 0.05 \\
\hline $81-85$ & 0 \\
\hline
\end{tabular}


Source: Employers Providence Fund: Annual Report 2016

Financial behaviour is also related to culture and social norms. They determine the extent of social support an individual gets in the matters related to finance (Taylor, Sherman, Kim, Jarcho, Takagi, \& Dunagan, 2004). Generally, in many cultures, students irrespective of their age; are mostly financially dependent on others. University students are expected to be more financially independent as compared to school students. Since the former are more mature than the latter, managing and living within a budget should be widely practised too.

Other than age, gender influences a person's financial behaviour. Fisher (2010) believes that males display better financial behaviour than females. The statistics provided by the Employers Providence Funds (EPF) (2016) proves the same, i.e, males' savings are higher than those of females. However, such a view must be taken with a pinch of salt. Only those working with large organisations will have their contributions in EPF. There are also many others, especially females, who are working, yet not having contributions in the EPF. As such, assuming that males have higher rate of savings or better money management must be investigated before making any conclusion.

Parents also play their part in a person's financial behavior. Parents' role is evident in the acquisition and development of values, attitudes, standards, norms, knowledge, and behaviours that are linked to financial management (Danes \& Heather, 2007). Parents' role may outweigh work experience or any financial education courses when it comes to the financial behaviour of college students (Shim, Xiao, Barber, \& Lyons, 2009). A young student will most likely rely on parents for support, especially in times of financial distress.

Parents' role in a child's learning is enormous (Kolb, 1984). The experiential learning theory emphasizes that observation supported with experience, conceptualising and experimenting are an integral part of learning. When it comes to financial management, children often learn about it through their parents' actions in managing money (Kim, Jaslean, \& Haejeong, 2011); (Serido, Curran, \& Wilmarth, 2015). Students' views are based on their observations over their parents' approaches towards financial management. Hence, when a student faces financial strain, decisions on whether to seek financial aid or borrow money from others, is often made by referring to what their parents' would have done in similar situations (Hibbert, Ivan, \& Todd, 2004) (Danes \& Heather, 2007).

However, knowing when and how to seek help when facing financial difficulties are commendable traits. Xiao (2014) regards seeking advice as a reflection of individual financial ability to manage own finances. As such, seeking advice to improve one's own financial behaviour and well-being should be encouraged (Schmeiser \& Hogarth, 2013). Though the relationship between academic achievement and wealth has not been clearly established, unhealthy financial status has its effect on students' academic achievements (Kelly, Hareel, Fontes, Walters, \& Murrhy, 2017). Besides academic achievement, financial status and in particular credit card debt, are highly associated with students' poor financial management behaviour (Robb \& Woodyard, 2011).

Findings of Worthy, Jonkman, \& Blinn-Pike (2010) highlighted that among young adults, 
college students are at high risk of facing financial problems which could lead to financial crisis. Hence, the distinction of this study lies in the sample of young adults who took part in the survey. Besides being young adults, the participants are also future teachers who themselves will be responsible for moulding future generations. Studying the financial behaviour of these future teachers augurs to some extent the financial literacy of future generations, for their actions, beliefs and views related to money could unintentionally be emulated by the students they teach.

A unique feature of the pre-service teachers who took part in this study is that their accommodation is provided and fully funded by the government. During their teacher education programme, they also receive monetary allowance. Though the support given by the Teacher Education Institute (TEI) is a noble act, it could also encourage the pre-service teachers to take unwarranted financial risks. The research has shown that the degree of financial risks is associated with the width of social network of a person (Mandel, 2003). The nature of the association between the width of social network and the degree of financial risks is still vague. At a glance, it looks like the wider the network, the higher the degree of financial risk one will take. Yet, Harvey and Alexander (2012) state that a wide social network is not necessarily translated into support received when a person is facing financial difficulties.

The uniqueness of this study also lies in its scope. There are numerous studies on how emotions impact decision-making under risk (Caplin \& Leahy, 2001). There are studies in the domain of neuro-science literature exploring how the emotional brain, i.e, the nucleus accumbens and anterior insula, is important for decision-making under risk. Instead of studying how risks affect emotions, the goal of this paper is to examine whether financial behaviour, particularly when it comes to expenditure planning, affects emotions of the pre-service teachers. The emotional state also depicts the stress levels.

Stress is an inevitable part of life and it can significantly affect both the mind and the body. Stress can be caused by people, places or events. Generally speaking, stress is caused by the internal state of an individual, the external state, or the interaction between a person and the environment (Travers \& Cooper, 1996; McNamara, 2000). Long periods of tension caused by day-to-day activities can also cause stress. There are two types of stress: eustress and distress. The former is considered to be good; while the latter (distress) can cause unhappiness (Wintroub \& Kleiner, 2015).

Stress and depression are the major problems faced by college students (Sasaki \& Yamasaki, 2007). Studies on stress level among college students show that the number of students experiencing stress is relatively high, fluctuating between moderate level (77.6\%) and serious (10.4\%), as cited in Dixon \& Kurplus (2008). One of the factors which could cause stress is lack of money. If stress levels go unchecked, stressful living conditions could affect college students' academic performance (Casino, 2009). Stress due to financial issues may even force some students to discontinue their studies (Lacey, 2013). 


\section{Data and Methodology}

The conceptual framework for this study is based on the study by Norvilitis, Merwin, Osberg, Roehling, Young, \& Kamas (2006). They have identified several factors which influence how college students manage their money. The factors are personality traits, knowledge and age. The pre-service teachers in this study are young adults. Liu, et al., (2017) defined young adults as those whose age is between 20-44. The pre-service teachers who took part in this study are of the same age, that is 23 years old. Hence the age factor is omitted.

For this study, a conceptual framework (shown in Figure 1) was designed to capture the financial behaviour of pre-service teachers. The arrows in the framework represent the relationship between the expenditure planning and the variables which influence it.

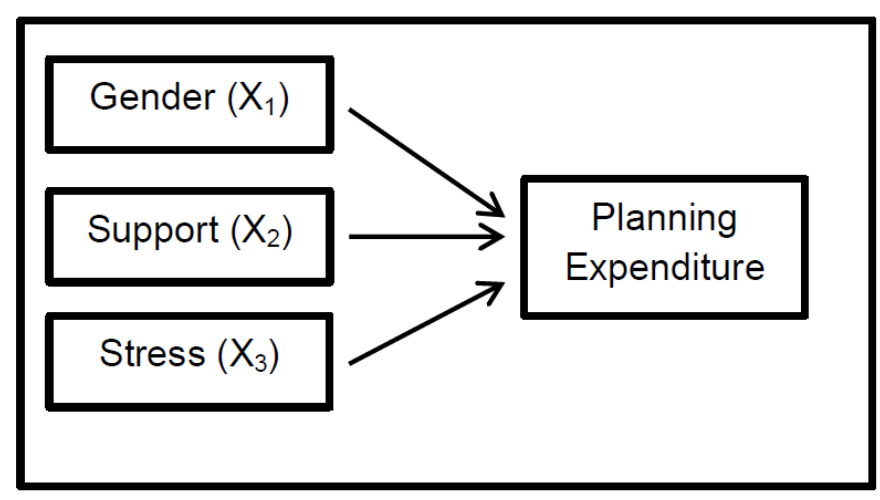

Figure 1. Conceptual framework for Expenditure Planning

An online survey was utilized to obtain data on the expenditure planning of the pre-service teachers. A total of 127 pre-service teachers responded to the online study. At the time of this study, the pre-service teachers were highly concerned with the delay in their monthly allowance. Prior to this study (in previous months), the pre-service teachers received their monthly allowance at the beginning of the month. However at the time of this study, the pre-service teachers had not received their allowance for the duration of three months.

The survey instrument consisted of three main parts. Five items in part 1 focussed on demographic questions. This is followed by four items on expenditure in part 2. They are "I plan my expenditure; I list all my expenditures; I write down all my expenses and I plan my expenditure in terms of priority". And finally in part three, eight items focussed on emotional stress. The emotional stress items were adapted from the 'Depression Anxiety Stress Scales (DASS). The response category used a four-point Likert-type scale from (1) totally disagree to (4) totally agree. Prior to administering the survey, it was shown to a counsellor to determine its validity. The Cronbach's alpha was 0.76 for these eight items, indicating an alpha that minimally meets the acceptable limit of 0.5 (Field, 2009). The eight items were added to get a composite value of stress.

The data was treated with two types of analyses. First, descriptive analysis was used to illustrate the demographic items and financial decisions i.e expenditure related. Second logistics regression was used to analyse financial decisions as the dependent variable with stress, gender and parental support as the independent variables. 
Logistic regression is an analysis method in which the dependent variable consists of a two-level or multiple-level categorical data. With logistic regression, the causality relationship between the dependent variable and independent variables can be determined (Bahadir, 2016). The dependent variable must be a categorical data, while the independent variable could be either continuous or categorical data (Işı̆̆ıçok, 2003). The effects of the independent variables on the dependent variable are calculated in the form of probability (Hosmer \& Lemeshow, 2000).

Logistic regression model is given as follows

$$
\pi(x)=\frac{e^{\beta_{o}+\beta_{x} x}}{1+e^{\beta_{0}+\beta_{1} x}}
$$

$\pi(x)$ is the conditional mean of $\mathrm{Y}$ (dependent variable) given $x$ (independent variable) i.e $\mathrm{E}(\mathrm{Y} / \mathrm{x})$. The value of dependent variable given independent variable can be expressed as $\mathrm{y}=$ $\pi(x)+\varepsilon, \varepsilon$ is the error term. If $\mathrm{y}=1$, then $\varepsilon=1-\pi(x)$ with probability $\pi(x)$ and if $\mathrm{y}=0, \varepsilon=-\pi(x)$ with probability $1-\pi(x)$. This means, $\varepsilon$ follows a binomial distribution with mean 0 and variance $\pi(x)[1-\pi(x)]$. A transformation of $\pi(x)$ is called a logit function which requires

$$
g(x)=\ln \left[\frac{\pi(x)}{1-\pi(x)}\right]=\beta_{0}+\beta_{1} x
$$

The difference between logit function when $x=1$ and $x=0$ is given as $g(1)-g(0)=\beta_{1}$. The results can be interpreted with a measure of association called odds ratio (OR). OR provides an approximation whether the response variable will occur or not among those with $x=1$ than among those with $\mathrm{x}=0$

$$
O R=\frac{\frac{\pi(1)}{1-\pi(1)}}{\frac{\pi(0)}{1-\pi(0)}}
$$

The dependent variable "Planning Expenditure" is a binary variable coded 1 for the pre-service teachers will plan their expenditure and 0 when the pre-service teachers will not plan their expenditure. The explanatory variables are Gender $\left(X_{1}: 1\right.$ for male, 2 for female), $\operatorname{Support}\left(\mathrm{X}_{2}\right.$ : 1 for parental support, 2 non-parental support) and Stress ( $\mathrm{X}_{3}$ : a composite value of the emotions which captures stress).

\section{Results}

A total of 127 pre-service teachers participated in the study. Participants were predominately female $(72 \%, n=91)$ with the majority staying in hostel $(65 \%, \mathrm{n}=83)$ and only a few owning vehicles $(36 \%, \mathrm{n}=46)$ (See Table $2 \& 3)$. Table 4 shows that comparatively male pre-service teachers seem to have planned their expenditures better than female pre-service teachers. 
Table 2. Profile of the pre-service teachers

\begin{tabular}{|l|c|c|c|c|c|c|}
\hline & \multicolumn{2}{|c|}{ Staying in Hostel } & \multicolumn{2}{c|}{ Owns Vehicle } & \multicolumn{2}{c|}{ Plans Expenditure } \\
\hline & Yes & No & Yes & No & Yes & No \\
\hline Male & 18 & 18 & 23 & 13 & 32 & 4 \\
\hline Female & 65 & 26 & 23 & 68 & 88 & 3 \\
\hline Total & 83 & 44 & 46 & 81 & 120 & 7 \\
\hline
\end{tabular}

Table 3 Ownership of vehicle and planning expenditure

\begin{tabular}{|l|c|c|}
\hline \multirow{2}{*}{ Plans Expenditure } & \multicolumn{2}{|c|}{ Owns Vehicle } \\
\cline { 2 - 3 } & Yes & No \\
\hline Yes & 44 & 76 \\
\hline No & 2 & 5 \\
\hline Total & 46 & 81 \\
\hline
\end{tabular}

Table 4. Planning expenditure by gender

\begin{tabular}{|l|c|c|c|c|}
\hline \multirow{3}{*}{ Planning Expenditure } & \multicolumn{4}{c|}{ Gender } \\
\cline { 2 - 5 } & \multicolumn{2}{|c|}{ Male } & \multicolumn{2}{c|}{ Female } \\
\cline { 2 - 5 } & Num & $\%$ & Num & $\%$ \\
\hline Plans Expenditure & 32 & 88.89 & 88 & 96.70 \\
\hline Does Not Plan Expenditure & 4 & 11.11 & 3 & 3.30 \\
\hline Total & 36 & 100 & 91 & 100 \\
\hline
\end{tabular}

Hosmer-Lemeshow test shows that the goodness of fit test statistics is not significant ( $\mathrm{p}$-value is 0.77 ) implying that the estimated model fits the data. Cox \& Snells $\mathrm{R}^{2}$ indicates that $18.6 \%$ of the variation is explained by the model, while Nagelkerke's $\mathrm{R}^{2}$ indicates a strong relationship of $53.5 \%$ between the predicted variable and explanatory variables (See Table 5).

Table 5. Goodness of Fit Statistics for Logistic Regression

\begin{tabular}{|c|c|c|c|c|c|c|}
\hline \multicolumn{4}{|c|}{ Model Summary } & \multicolumn{3}{c|}{ Hosmer and Lemeshow Test } \\
\hline Step & -2 Log likelihood & Cox \& Snell R-square & Nagelkerke R-square & Chi-square & df & Sig \\
\hline 1 & 28.09 & 0.186 & 0.535 & .693 & 8 & 0.776 \\
\hline
\end{tabular}

The parameter estimation of the model, the Wald statistic and the significance level of the independent variables in the model are shown in Table 6. The Wald statistic is significant (i.e less than 0.05) which indicates that the variables in the model are significant. The independent variables, stress and gender, have been significantly affected by the dependent variable i.e planning expenditure.

Table 6. Estimation Results for Logistic Regression

\begin{tabular}{|l|c|c|c|c|c|c|}
\hline & B & S.E. & Wald & df & Sig. & $\operatorname{Exp(B)}$ \\
\hline Constant & 27.794 & 9.534 & 8.498 & 1 & .004 & 8.560 \\
\hline Stress & -7.461 & 2.752 & 7.347 & 1 & .007 & .001 \\
\hline Support & -.077 & 1.294 & .004 & 1 & .953 & .926 \\
\hline Gender & -2.217 & 1.113 & 3.972 & 1 & .046 & .109 \\
\hline
\end{tabular}




\section{MlMacrothink}

Business and Economic Research

ISSN 2162-4860

2018, Vol. 8, No. 3

The independent variable "support" is a representation of parental support. This is not surprising as the teaching course is very popular among school leavers. This can be seen in the number of applicants the Ministry of Education receives each year. Compounded with job security, upon completion of studies, teacher training is favoured by many because a living allowance is given to students pursuing this course. Many parents encourage their children to pursue teacher training, for it reduces their financial burden in giving their child a tertiary education. In addition, many pre-service teachers are aware of their parents' financial constraints and relying on financial support from them can be limiting.

\section{Policy Recommendations}

Unlike other college students (Dwyer, McCloud, \& Hodson, 2013), pre-service teachers' financial status is unlikely to impact their career prospects. However, this does not mean that pre-service teachers have the privilege of amassing debt. Debt accumulated during their college days will have an influence during the later years. It is important that during their tenure in Teacher Education Institute (TEI), pre-service teachers are able to manage their finances well, and if possible start their career (teaching) debt free.

One's financial situation can have an effect on one's general satisfaction and well-being (Zimmerman, 1995). Unhealthy financial situations Pre-service teachers could affect their academic performance. If this is left unchecked, it could lead to the off-railing intentions of Ministry of Education Malaysia in producing quality teachers who are able to serve in schools.

Pre-service teachers must be exposed to financial matters (Grohmann \& Menkhoff, 2015). The term financial socialization best describes the steps taken in exposing people to the theoretical knowledge of financial matters, which eventually will influence or uplift a person's financial behaviour.

A person is said to have financial knowledge when he has some basic knowledge on financial concepts and the ability to apply numeracy skills on financial matters. It would be good during teacher training that teachers are exposed to financial literacy. The financial behaviour of individuals with financial education has positive effects on a person's ability to manage their finances (Lusardi, 2004). In fact, studies show that those who studied economics or business are good in managing their money (Grimes, Rogers, \& Smith, 2010). Therefore, it would be good if pre-service teachers are exposed to finance and education. At present only pre-service teachers specialising in "teaching Mathematics" is required to take a subject on financiall mathematics. In this course, they are exposed to a few financial concepts such as time value of money and net present value.

Instead of making it a compulsory subject, Teacher Education Institute could invite professionals who are trained in personal financing to conduct credit management classes with the pre-service teachers. Cole, Paulson, \& Shastry's (2014) study showed that there was an improvement in the financial decisions made by people in United States of America who had the privilege of attending or taking courses related to credit management.

Upon graduation, pre-service teachers would begin to receive salary which will be higher 
than the allowance they are receiving currently. If this increase is not managed well, it could lead to many unwanted financial situations. This is where financial prudence comes into play. Having knowledge of financial literacy would help these pre-service teachers to face this these unwanted financial situations. IBRD (2009) believes financial literacy is critical in promoting changes in financial behaviour. Therefore, it is critical that MOE includes a financial management course into the curriculum of teacher education.

\section{Reference}

Bahadir, E. (2016, June). Using Neural Network and Logistic Regression Analysis to Predict Prospective Mathematics Teachers' Academic Success upon Entering Graduate Education. Educational Sciences: Theory and Practice, 16(3), 943-964.

https://doi.org/10.12738/estp.2016.3.0214.

Caplin, A., \& Leahy, J. (2001). Psychological Expected Utility Theory and Anticipatory Feelings. Quarterly Journal of Economics, 116, 55-79.

https://doi.org/10.1162/003355301556347.

Casino, L. I. (2009). The relationship among living situation, health, and college academic performance. Retrieved September 26, 2017. [Online] Available:

http://clearinghouse.missouriwestern,edu/manuscripts/s/z.php.

Cole, S., Paulson, A., \& Shastry, G. K. (2014). Smart money? The effect of education on financial outcomes. Review of Financial Studies, 27(7), 2022-2051.

https://doi.org/10.1093/rfs/hhu012.

Danes, S. M., \& Heather, H. R. (2007). Teen Financial Knowledge, Self-Effcacy, and Behavior: A Gendered View. Journal of Financial Counseling and Planning, 18(2), 48-60.

Dixon, S. K., \& Kurplus, S. R. (2008). Depression and college stress among university undergraduates: Do mattering and self-esteem make a difference?. Journal of College Student Development, 49(5), 412-424. https://doi.org/10.1353/csd.0.0024.

Dwyer, R. E., McCloud, L., \& Hodson, R. (2013). Debt, gender, and dropping out of college. Gender \& Society, 27(1), 30-55. https://doi.org/10.1177/0891243212464906

Field, A. (2009). Discovering statistics using SPSS (3 ed.). London: Sage.

Fisher, P. J. (2010). Gender differences in personal saving behaviors. Journal of Financial Counseling and Planning, 21, 14-24.

Grable, J. E., \& Joo, S. H. (2006). Student racial differences in credit card debt and financial behaviors and stress. College Student Journal, 40(2), 400-408.

Grimes, P. W., Rogers, K. E., \& Smith, R. C. (2010). High school economic education and access to financial services. Journal of Consumer Affairs, 44, 317-335.

https://doi.org/10.1111/j.1745-6606.2010.01171.x.

Grohmann, A., \& Menkhoff, L. (2015, July 29). School, parents, and financial literacy shape future financial behaviour. DIW Economic Bulletin, 3(30/31), 407-412. 
Harvey, I. S., \& Alexander, K. (2012). Perceived social support and preventive health behavioural outcomes among older women. Journal of Cross Cultural Gerontology, 27, 275-290. https://doi.org/10.1007/s10823-012-9172-3

Henry, R. A., Weber, J. G., \& Yarbarough, D. (2001). Money management practices of college students. College Student Journal, 35(2), 244-249.

Hibbert, J. R., Ivan, B. F., \& Todd, M. M. (2004). Financial Prudence and Next Generation Financial Strain. Journal of Financial Counseling and Planning, 15(2), 51.

Hosmer, W. D., \& Lemeshow, S. (2000). Applied Logistic Regression (2 ed.). New York: Wiley-Interscience Publication. https://doi.org/10.1002/0471722146..

Işı̆̆ıçok, E. (2003). Analyzed by logistic regression analysis of the factors affecting birth weight and length of the Baby. VI Ulusal Ekonometri ve İstatistik Sempozyumu, (p. 5). Gazi Üniversitesi İktisadi ve İdari Bilimler Fakültesi E.

Kelly, N., Hareel, T., Fontes, A., Walters, C., \& Murrhy, J. (2017, Spring). An Examination Of Social Desirability Bias In Measures Of College Students' Financial behavior. College Student Journal, 51(1), 115-128.

Kim, J., Jaslean, L., \& Haejeong, K. (2011). Family Processes and Adolescents' Financial Behavior. Journal of Family and Economic Issues, 32, 668-679.

https://doi.org/10.1007/s10834-011-9270-3.

Kolb, D. A. (1984). Experiential Learning: Experience as the Source of Learning and Development. Englewood Cliffs, NJ: Prentice-Hall, Inc.

Lacey, K. (2013). Two-year students face more money stress. University Business, 16(7), 18.

Liu, X., Xiang, Z., Shi, X., Schenck, H., Yi, X., Ni, R., \& Liu, C. (2017, August 28). The Risk Factors of High Blood Pressure among Young Adults in the Tujia-Nationality Settlement of China. BioMed Research International, 1-6. https://doi.org/10.1155/2017/8315603

Lusardi, A. (2004). Saving and the effectiveness of financial education. Pension Design and Structure. In O. Mitchell, \& W. Utkus, New Lessons from Behavioral Finance (pp. 157-184). Cambridge: Oxford University Press.

Mandel, N. (2003). Shifting selves and decision making: The effects of self-construal priming on consumer risk-taking. Journal of Consumer Research, 30, 30-40.

https://doi.org/10.1086/374700.

McNamara, S. (2000). Stress in young people. London: The Cromwell Press.

Norvilitis, J. M., Merwin, M. M., Osberg, T. M., Roehling, P. V., Young, P., \& Kamas, M. M. (2006). Personality factors, money attitudes, financial knowledge and credit card debt in college students. Journal of Applied Social Psychology, 36, 1395-1413.

https://doi.org/10.1111/j.0021-9029.2006.00065.x.

Robb, C., \& Woodyard, A. S. (2011). Financial knowledge and best practice behavior. 
Journal of Financial Counseling and Planning, 22(1), 60-70.

Sasaki, M., \& Yamasaki, K. (2007). Stress coping and the adjustment process among university freshmen. Counselling Psychology Quarterly, 20(1), 51-67.

https://doi.org/10.1080/09515070701219943.

Schmeiser, M. D., \& Hogarth, J. M. (2013). Good Advice, Good Outcomes? How Financial Advice-Seeking Relates to Self-Perceived Financial Well-Being. Retrieved September 26, 2017. [Online] Available: http://papers.ssrn.com/sol3/papers.cfm?abstract_id=2261707.

Serido, J., Curran, M. J., \& Wilmarth, M. (2015, Dec). The Unique Role of Parents and Romantic Partners on College Students' Financial Attitudes and Behaviors. Family Relations, 64(5), 696-710. https://doi.org/10.1111/fare.12164.

Settersten, R. J. (2012). The contemporary context of young adulthood in the USA: From demography to development, from private troubles to public issues. In A. Booth, S. L. Brown, N. S. Landale, \& W. D. Manning, Early adulthood in a family context (pp. 3-26). New York: Springer. https://doi.org/10.1007/978-1-4614-1436-0_1.

Shim, S., Xiao, J. J., Barber, B. L., \& Lyons, A. C. (2009). Pathways to life success: A conceptual model of financial well-being for young adults. Journal of Applied Developmental Psychology, 30, 708-723. https://doi.org/10.1016/j.appdev.2009.02.003.

Taylor, S. E., Sherman, D. K., Kim, H. S., Jarcho, J., Takagi, K., \& Dunagan, M. S. (2004). Culture and social support: Who seeks it and why?. Journal of Personality and Social Psychology, 87, 354-362. https://doi.org/10.1037/0022-3514.87.3.354

Travers, C. J., \& Cooper, C. L. (1996). Teachers under pressure: stress in the teaching profession. London, UK: Routledge.

Wintroub, M., \& Kleiner, B. (2015, June). Excellence In Managing Individual Stress. Insights to a Changing World Journal, 2, 48.

Worthy, S. L., Jonkman, J., \& Blinn-Pike, L. (2010, June). Sensation-Seeking, Risk-Taking, and Problematic Financial Behaviors of College Students. Journal of Family and Economic, 31(2), 161-170. https://doi.org/10.1007/s10834-010-9183-6.

Xiao, J. J. (2014). Consumer Financial Capability and Financial Satisfaction. Social Indicators Research, 1(118), 415-432. https://doi.org/10.1007/s11205-013-0414-8.

Zimmerman, S. L. (1995). Understanding family policy: Theories and applications (2 ed.). Thousand Oaks, CA: Sage.

\section{Copyright Disclaimer}

Copyright for this article is retained by the author(s), with first publication rights granted to the journal.

This is an open-access article distributed under the terms and conditions of the Creative Commons Attribution license (http://creativecommons.org/licenses/by/3.0/). 